\title{
The effects on human gastric secretion of prolonged continuous intravenous infusions of maximal and supramaximal doses of histamine acid phosphate and pentagastrin
}

\author{
D. A. AUBREY \\ From the University Department of Surgery, Welsh National School of Medicine, and United Cardiff \\ Hospitals
}

SUMMARY The effects of continuous intravenous infusions of 'maximal' and 'supramaximal' doses of histamine acid phosphate and pentagastrin were assessed in a normal human volunteer. The secretory patterns in respect of the two drugs were indistinguishable over two and a quarter hours. During the steady states of acid secretion, outputs of pepsin and of electrolytes were also constant. The output of acid during the first hour of the steady state is a valid measurement of the maximal secretory capacity. The constant output of pepsin during the steady state of acid secretion suggests that both drugs are true stimulants of pepsin secretion.

-

After a single subcutaneous injection of histamine acid phosphate, as in the augmented histamine test (Kay, 1953), the output of acid rises towards a peak, which is transient and occurs at a variable time during the first hour after the administration of the drug (Baron, 1963). The transient nature of this response leaves considerable room for error in the estimation of the maximal output of acid, particularly in states characterized by low secretion (Lawrie, Smith, and Forrest, 1964). When a maximal dose of histamine or pentagastrin is administered by continuous intravenous infusion the output of acid rises to reach a plateau or steady state (Lawrie et al, 1964; Konturek and Lankosz, 1967). The calculation of the maximal secretory capacity is not then dependent on the observation and interpretation of a peak response, and hence there is less room for error in calculating the maximal output of acid than in the augmented histamine test.

The study reported now was undertaken to determine respectively (1) whether the maximal gastric secretory outputs of acid, pepsin, and electrolytes were sustained when histamine acid phosphate and pentagastrin were administered, by continuous intravenous infusion, for prolonged periods, and (2) whether the outputs of these constituents in the first hour of steadystate conditions were a valid assessment of this state.

Received for publication 21 October 1969.
Methods

TESTS OF SECRETION

Twelve tests of gastric secretion were performed on one subject, a normal healthy male volunteer aged 52 years. He received in random sequence, on three occasions each, 40 and $80 \mu \mathrm{g} / \mathrm{kg} / \mathrm{hr}$ of histamine acid phosphate and 6.0 and 12.0 $\mu \mathrm{g} / \mathrm{kg} / \mathrm{hr}$ of pentagastrin. Each test was preceded by a fast of at least 12 hours, and at least three days intervened between tests.

In the tests using histamine, a prior injection $\stackrel{N}{\sigma}$ of mepyramine maleate was given to counteract $N$ side effects; $50 \mathrm{mg}$ was given before a dose $\underset{\mathrm{N}}{\mathcal{N}}$ of $40 \mu \mathrm{g} / \mathrm{kg} / \mathrm{hr}$ and $100 \mathrm{mg}$ before a dose of $80 \mu \mathrm{g} / \mathrm{kg} / \mathrm{hr}$.

The stimulants were diluted in $0.9 \%$ saline, and their concentrations in solution were $\stackrel{\oplus}{+}$ dependent on the dose required according to $\square$ body weight. The rates of infusion were controlled by a Palmer constant infusion pump and varied from 5.37 to $11.74 \mathrm{ml}$ per hour.

The technique of performing the secretory tests was identical to that described previously by Lawrie and his colleagues (1964). After응 emptying the stomach, basal (unstimulated) gastric juice was collected for 30 minutes, and $\frac{\bar{a}}{2}$ then the stimulant was administered, by continuous intravenous infusion, for two and a quarter hours. Throughout the test, gastric juice was continuously collected in 15 -minute samples. 

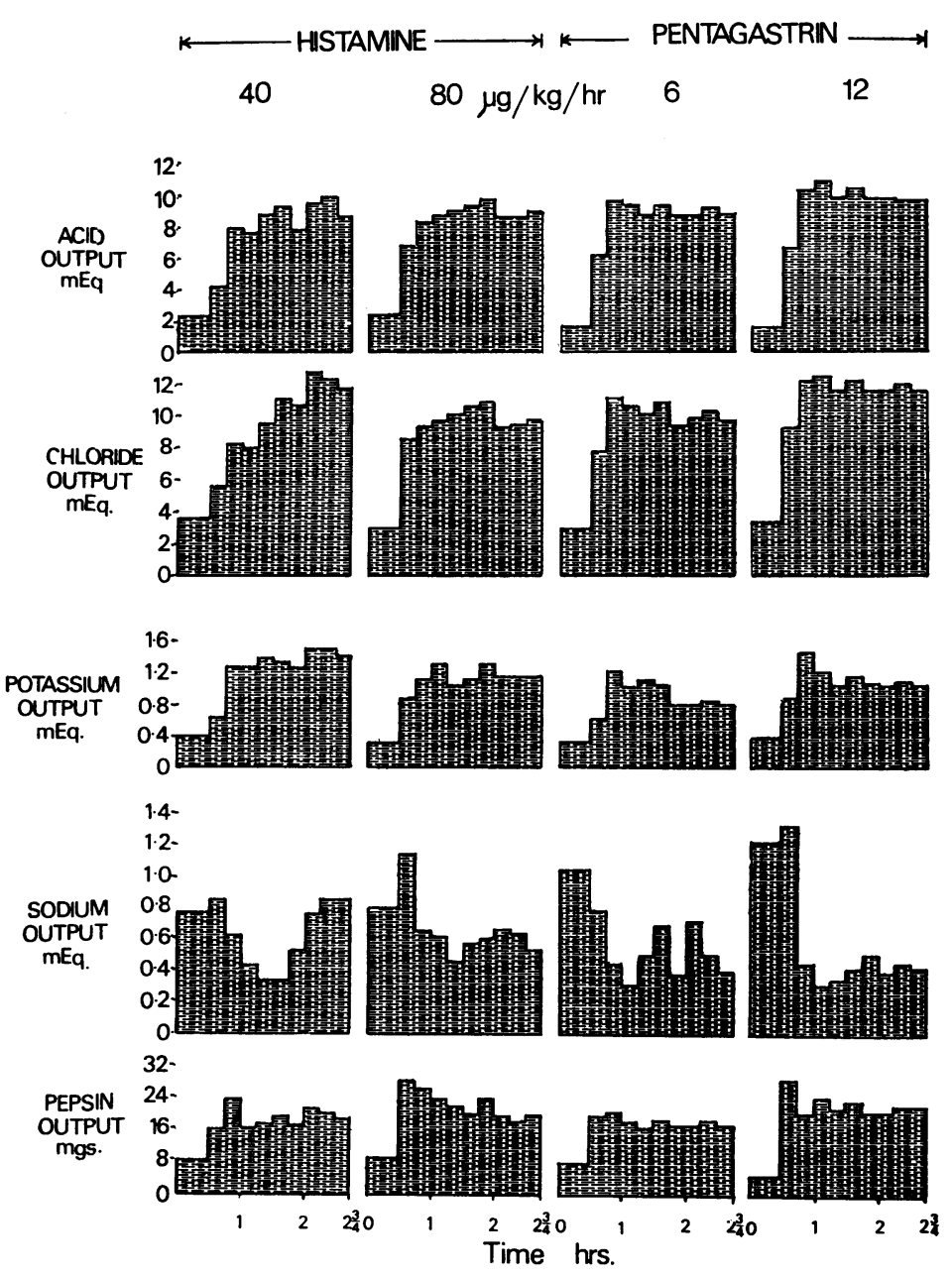

Fig. The mean outputs of the components in gastric juice, per 15 minutes, in one normal subject, before and during stimulation by histamine acid phosphate and pentagastrin. Each 15-minute output is the mean of three correspondingly timed outputs in three tests. The infusions were begun after the second 15-minute period.
The concentrations of the hydrogen $\left(\mathrm{H}^{+}\right)$, sodium $\left(\mathrm{Na}^{+}\right)$, potassium $\left(\mathrm{K}^{+}\right)$, and chloride $\left(\mathrm{Cl}^{-}\right)$ions, and of pepsin were determined, in duplicate, in each 15-minute sample of gastric juice, and the means of the duplicate values were taken. The $\mathrm{H}^{+}$concentration was determined on aliquots of $10 \mathrm{ml}$ of undiluted gastric juice, by titration with $0.1 \mathrm{~N} \mathrm{NaOH}$ to a $p \mathrm{H}$ of $7 \cdot 0$, using a Radiometer automatic titrator (type PPPIC). The concentration of pepsin was determined on aliquots of $0.2 \mathrm{ml}$ of undiluted gastric juice, using radioiodinated human albumin as the substrate, by the method of Klotz and Duvall (1957). The concentrations of the $\mathrm{Na}^{+}$ and $\mathrm{K}^{+}$were determined, by flame photometry, using $0 \cdot 1 \mathrm{ml}$ aliquots of gastric juice, appropriately diluted with deionized water. The concentration of the $\mathrm{Cl}^{-}$was determined on undiluted gastric juice by means of a chloride meter. The output of a constituent of the gastric juice was calculated as the product of the volume of the sample and the concentration of the constituent in it.

\section{Results}

The pattern of secretion in response to each dose of both drugs is shown in the Figure. Each 15minute output is the mean of three correspondingly timed responses in three separate tests. The outputs of acid, chloride, and potassium increased until plateau values were reached. The output of sodium fell, but became approximately constant when the steady state of acid secretion was achieved. There was an initial transient peak output of pepsin, followed by a lower, more constant output which was in excess of that found in basal secretions.

In each test, 60-minute outputs of each constituent of the gastric juice were calculated from four successive 15-minute outputs, beginning 15 minutes after the start of the infusion. For each constituent, these 60-minute outputs were clearly similar. Those of acid and pepsin are shown in Table I.

\begin{tabular}{|c|c|c|c|c|c|c|c|c|c|c|c|}
\hline \multirow[t]{3}{*}{ Stimulant } & \multirow[t]{3}{*}{ Test } & \multicolumn{5}{|c|}{ Acid Output (m-Equiv/60 minutes) } & \multicolumn{5}{|c|}{ Pepsin Output (mg/60 minutes) } \\
\hline & & \multicolumn{5}{|c|}{ Time after the Start of the Infusions (minutes) } & \multicolumn{5}{|c|}{ Time after the Start of the Infusions (minutes) } \\
\hline & & 15 to 75 & 30 to 90 & 45 to 105 & 60 to 120 & 75 to 135 & 15 to 75 & 30 to 90 & 45 to 105 & 60 to 120 & 75 to 135 \\
\hline $\begin{array}{l}\text { Histamine } \\
40 \mu \mathrm{g} / \mathrm{kg} / \mathrm{hr}\end{array}$ & $\begin{array}{l}1 \\
2 \\
3\end{array}$ & $\begin{array}{l}35 \cdot 66 \\
29 \cdot 08 \\
34 \cdot 74\end{array}$ & $\begin{array}{l}34 \cdot 84 \\
28 \cdot 16 \\
36 \cdot 35\end{array}$ & $\begin{array}{l}35 \cdot 79 \\
31 \cdot 20 \\
37 \cdot 38\end{array}$ & $\begin{array}{l}35 \cdot 75 \\
32 \cdot 27 \\
39 \cdot 22\end{array}$ & $\begin{array}{l}36 \cdot 27 \\
29 \cdot 47 \\
39 \cdot 83\end{array}$ & $\begin{array}{l}83 \cdot 88 \\
69 \cdot 01 \\
77 \cdot 22\end{array}$ & $\begin{array}{l}73 \cdot 05 \\
65 \cdot 75 \\
73 \cdot 33\end{array}$ & $\begin{array}{l}74 \cdot 46 \\
73 \cdot 36 \\
77 \cdot 71\end{array}$ & $\begin{array}{l}74 \cdot 86 \\
77 \cdot 62 \\
81 \cdot 11\end{array}$ & $\begin{array}{l}77 \cdot 73 \\
77 \cdot 19 \\
78 \cdot 66\end{array}$ \\
\hline $\begin{array}{l}\text { Histamine } \\
80 \mu \mathrm{g} / \mathrm{kg} / \mathrm{hr}\end{array}$ & $\begin{array}{l}1 \\
2 \\
3\end{array}$ & $\begin{array}{l}33 \cdot 76 \\
34 \cdot 52 \\
36 \cdot 26\end{array}$ & $\begin{array}{l}34 \cdot 00 \\
36 \cdot 20 \\
38 \cdot 46\end{array}$ & $\begin{array}{l}33 \cdot 05 \\
37 \cdot 01 \\
38 \cdot 50\end{array}$ & $\begin{array}{l}32 \cdot 74 \\
36 \cdot 96 \\
37 \cdot 81\end{array}$ & $\begin{array}{l}32 \cdot 19 \\
36 \cdot 66 \\
37 \cdot 27\end{array}$ & $\begin{array}{l}83 \cdot 56 \\
93 \cdot 13 \\
98 \cdot 58\end{array}$ & $\begin{array}{l}78 \cdot 52 \\
94 \cdot 32 \\
94 \cdot 29\end{array}$ & $\begin{array}{l}75 \cdot 03 \\
88 \cdot 00 \\
91 \cdot 20\end{array}$ & $\begin{array}{l}76 \cdot 92 \\
79 \cdot 59 \\
86 \cdot 33\end{array}$ & $\begin{array}{l}73.48 \\
81 \cdot 08 \\
87.43\end{array}$ \\
\hline $\begin{array}{l}\text { Pentagastrin } \\
6 \mu \mathrm{g} / \mathrm{kg} / \mathrm{hr}\end{array}$ & $\begin{array}{l}1 \\
2 \\
3\end{array}$ & $\begin{array}{l}38 \cdot 83 \\
43 \cdot 58 \\
27 \cdot 03\end{array}$ & $\begin{array}{l}37 \cdot 76 \\
42 \cdot 60 \\
26 \cdot 45\end{array}$ & $\begin{array}{l}37 \cdot 27 \\
39 \cdot 75 \\
27 \cdot 22\end{array}$ & $\begin{array}{l}38 \cdot 62 \\
38 \cdot 45 \\
27 \cdot 57\end{array}$ & $\begin{array}{l}38 \cdot 79 \\
37 \cdot 12 \\
27 \cdot 76\end{array}$ & $\begin{array}{l}71 \cdot 01 \\
76 \cdot 52 \\
73 \cdot 92\end{array}$ & $\begin{array}{l}66 \cdot 80 \\
72 \cdot 31 \\
73 \cdot 55\end{array}$ & $\begin{array}{l}66 \cdot 24 \\
68 \cdot 65 \\
74 \cdot 25\end{array}$ & $\begin{array}{l}75 \cdot 23 \\
63 \cdot 23 \\
74 \cdot 19\end{array}$ & $\begin{array}{l}78 \cdot 51 \\
58 \cdot 22 \\
74 \cdot 43\end{array}$ \\
\hline $\begin{array}{l}\text { Pentagastrin } \\
12 \mu \mathrm{g} / \mathrm{kg} / \mathrm{hr}\end{array}$ & $\begin{array}{l}1 \\
2 \\
3\end{array}$ & $\begin{array}{l}41 \cdot 83 \\
39 \cdot 37 \\
40 \cdot 09\end{array}$ & $\begin{array}{l}39 \cdot 74 \\
39 \cdot 14 \\
41 \cdot 42\end{array}$ & $\begin{array}{l}38 \cdot 12 \\
39 \cdot 25 \\
40 \cdot 34\end{array}$ & $\begin{array}{l}37 \cdot 31 \\
40 \cdot 14 \\
40 \cdot 08\end{array}$ & $\begin{array}{l}37 \cdot 09 \\
39 \cdot 39 \\
39 \cdot 39\end{array}$ & $\begin{array}{l}84 \cdot 09 \\
96 \cdot 75 \\
81 \cdot 84\end{array}$ & $\begin{array}{r}79 \cdot 66 \\
100.95 \\
82.84\end{array}$ & $\begin{array}{r}77 \cdot 10 \\
100 \cdot 19 \\
80 \cdot 72\end{array}$ & $\begin{array}{r}79 \cdot 77 \\
104 \cdot 25 \\
76 \cdot 97\end{array}$ & $\begin{array}{l}78 \cdot 20 \\
99 \cdot 64 \\
80 \cdot 59\end{array}$ \\
\hline
\end{tabular}




\begin{tabular}{|c|c|c|c|c|c|c|c|c|c|c|c|c|}
\hline \multirow[t]{3}{*}{ Test } & \multicolumn{6}{|c|}{ Histamine } & \multicolumn{6}{|c|}{ Pentagastrin } \\
\hline & \multicolumn{3}{|c|}{$40 \mu g / k g / h r$} & \multicolumn{3}{|c|}{$80 \mu g / k g / h r$} & \multicolumn{3}{|c|}{$6 \mu g / k g / h r$} & \multicolumn{3}{|c|}{$12 \mu g / k g / h r$} \\
\hline & 1 & 2 & 3 & $I$ & 2 & 3 & 1 & 2 & 3 & 1 & 2 & 3 \\
\hline $\begin{array}{l}\text { Acid } \\
\text { Pepsin } \\
\text { Sodium } \\
\text { Potassium } \\
\text { Chloride }\end{array}$ & $\begin{array}{l}0.19 \\
0.41 \\
0.04 \\
0.06 \\
0.65^{2}\end{array}$ & $\begin{array}{c}0.12 \\
-0.43 \\
0.08 \\
0.01 \\
1.03^{2}\end{array}$ & $\begin{array}{r}0.26 \\
-0.11 \\
0.07 \\
0.02 \\
0.28\end{array}$ & $\begin{array}{l}-0.06 \\
-0.59 \\
-0.00 \\
-0.04 \\
-0.12\end{array}$ & $\begin{array}{c}0.13 \\
-1.06^{2} \\
-0.05 \\
-0.01 \\
0.09\end{array}$ & $\begin{array}{r}0.02 \\
-1.12^{2} \\
0.04 \\
0.04 \\
-0.03\end{array}$ & $\begin{array}{r}-0.04 \\
-0.03 \\
0.06 \\
-0.05 \\
-0.15\end{array}$ & $\begin{array}{l}-0.29 \\
-0.95^{2} \\
-0.05 \\
-0.07 \\
-0.43\end{array}$ & $\begin{array}{r}0.03 \\
0.33 \\
0.03 \\
-0.05 \\
0.11\end{array}$ & $\begin{array}{r}-0.30 \\
-0.29 \\
0.01 \\
-0.04 \\
-0.36\end{array}$ & $\begin{array}{c}0.00 \\
0.46 \\
-0.02 \\
-0.06 \\
0.04\end{array}$ & $\begin{array}{r}0.01 \\
0.01 \\
0.04 \\
-0.03 \\
0.07\end{array}$ \\
\hline
\end{tabular}

Table II Regression coefficients of the outputs of the different constituents of the gastric juice, on time, for the last eight $\times 15$-minute estimations in each test ${ }^{1}$

${ }^{1}$ There is a statistically significant trend whon the regression coefficient $>0.6$.

'Indicates that there is a statistically significant trend.

In order to determine whether there was a statistically significant alteration in the outputs of the different constituents of the gastric juice, after the first 15 minutes of stimulation, the regression coefficient of each variable, on time, was calculated in each test. Each analysis was therefore based on the last eight $\times 15$-minute outputs in each test. A regression coefficient larger than 0.6 would be statistically significant and would imply that there was a trend for the variable to change with time. The regression coefficients obtained in these analyses are shown in Table II. In only three of the groups of analyses were they greater than 0.6 . This was in the cases of the chloride output stimulated by $40 \mu \mathrm{g} / \mathrm{kg} / \mathrm{hr}$ of histamine and the pepsin output stimulated by $80 \mu \mathrm{g} / \mathrm{kg} / \mathrm{hr}$ of histamine and $6 \mu \mathrm{g} / \mathrm{kg} / \mathrm{hr}$ of pentagastrin. In all of the remaining analyses, there was no tendency for the outputs of the various constituents to alter, with time, during the last eight $\times 15$-minute periods of stimulation. It is therefore justifiable to select any 60-minute period during this time to calculate the plateau hour output of any of the constituents which were measured.

\section{Comment}

There was no difference in the gastric secretory pattern when 'maximal' and 'supramaximal' doses of histamine acid phosphate and pentagastrin were administered by continuous intravenous infusion for two and a quarter hours. With both drugs, the steady state of gastric acid secretion was maintained, without evidence of fatigue, at the end of this period of time.

The output of acid in the first hour of the steady state was a valid measurement of this state. The outputs of the electrolytes and generally those of pepsin were also sustained throughout the steady state of acid secretion. The steady state, therefore, is not only one of acid secretion tut also of electrolyte and of pepsin secretion.

From the establishment of steady-state conditions with either drug, the output of pepsin was sustained at levels more than twice that found in resting gastric juice. This finding would support the suggestion that a washout of preformed pepsin does not totally explain the pepsin response following stimulation with these drugs (Bucher, Ivy, and Gray, 1941; Hirschowitz, London, and Pollard, 1957; Gillespie and Bowen, 1962; Makhlouf, McManus, and Card, 1967). The initial peak response could be compatible with such a washout effect, but the continuing steady state of pepsin secretion would suggest that both drugs are true stimulants of the pepsin-forming cells.

I should like to thank Professor A. P. M. Forrest for his keen support and encouragement; Dr H. Campbell, senior lecturer in statistics, and Dr T. Khosla, lecturer in statistics, Welsh National School of Medicine, for their help with the statistics; $\mathrm{Mr} \mathrm{H}$. Kincaid and his staff for technical assistance; $\mathbf{M r} \mathbf{N}$. Pearce for the illustrations; and Mrs O. Palmer for her secretarial work.

The studies were performed at the Surgical Research Laboratories of the Welsh National School of Medicine, when the author was in receipt of a full-time grant from the Clinical Research Committee of the Welsh Regional Hospital Board.

References

Baron, J. H. (1963). An assessment of the augmented histamine $\omega$ test in the diagnosis of peptic ulceration: correlations between gastric secretion, age, and sex of patients and $C$ site and nature of the ulcer. Gut, 4, 243-253.

Bucher, G. R., Ivy, A. C., and Gray, J. S. (1941). Is histamine $\mathscr{D}$ able to maintain augmented pepsin response comparable : to that of pilocarpine? Amer. J. Physiol., 132, 698-706.

Gillespie, I. E., and Bowen, D. J. (1962). The gastric secretion of pepsin in man. Gut, 3, 255-259.

Hirschowitz, B. I., London, J. L., and Pollard, H. M. (1957). Histamine stimulation of gastric pepsin secretion in man. (D) Gastroenterology, 32, 85-87.

Kay, A. W. (1953). Effect of large doses of histamine on gastric $\sigma$ secretion of $\mathrm{HCl}$ : an augmented histamine test. Brit. med. J., 2, 77-80

Klotz, A. P., and Duvall, M. R. (1957). The laboratory determination of pepsin in gastric juice with radioactive iodinated albumin. J. Lab. clin. Med., 50, 753-757.

Konturek, S. J., and Lankosz, J. (1967). Pentapeptide infusion test. Scand. J. Gastroent., 2, 112-117.

Lawrie, J. H., Smith, G. M. R., and Forrest, A. P. M. (1964). The histamine-infusion test. Lancet, 2, 270-273.

Makhlouf, G. M., McManus, J. P., and Card, W. I. (1967). Comparative effects of gastrin II and histamine on pépsin secretion in man. Gastroenterology, 52, 787-789. 